\title{
Effect of Corporate Taxation on the Profitability of Firms in NIGERIA
}

\author{
Olaoye, Clement Olatunji, Alade, Elizabeth Oluwatoyin \\ Department of Accounting, Faculty of Management Sciences, Ekiti State University, Ado-Ekiti, Nigeria \\ clement.olaoye@eksu.edu.ng, toyinalade02@yahoo.com
}

\begin{abstract}
The paper examined the effect of corporate taxation on the profitability of some selected firms in Nigeria from 2007 to 2016 using secondary data which was sourced from various publications of the firms' financial report. The study employed pooled ordinary least square as the estimation technique. The analytical results revealed that the coefficient of corporate tax on profit after tax was positive with the value of 2.418830 and its P-values were 0.0000 , the coefficient of value-added tax was 14.51298 and its p-value was 0.0000 . Equally, the coefficient of withholding tax was positive with the value of 7.256489 with p-value 0.0000 . Furthermore, education tax result depicts that the coefficient is 36.28245 and it p-value is 0.0000 . However, the study concluded that corporate tax rate and education tax as the major taxes paid by companies have positive and significant effects to influence profit after tax. It is also clinched that value-added tax rate and withholding tax being used as other variables that could have effects on profit after tax equally revealed positive and significant effects on profit after tax. Therefore, the study recommended that the government and relevant tax authorities should improve in the administration of corporate taxes to avoid non-compliance
\end{abstract}

Keywords: Taxation, Corporate Taxation, Profit after Tax, Education Tax

\section{Introduction}

The engagement of government in providing social amenities in developmental projects is a compulsory phenomenon for the improvement of standard of living of the citizenry (Madugba, Ekwe \& Kalu, 2015). This however necessitated the government to source for fund from various sources where corporate taxes are not left out. (Madugba, et al., 2015) defined tax as compulsory levies impose by the government of a nation on the income, profit and properties of both individuals and corporate bodies for the administration of the government which has no compensatory benefits. Taxation can either be direct or indirect paid by firm impact heavily on their performance (Nwaobia \& Jayeoba, 2016). The direct taxes borne by companies can be company income tax, petroleum profit tax, capital gain tax, education tax, withholding tax etc. equally, the indirect taxes borne by the final consumer for the consumption of goods or services includes value-added tax, and custom and excise duties. However, corporate tax is charged on the profits generated by companies, public corporations and unincorporated associations such as industrial and provident societies, clubs and trade associations (Raza, Ali \& Abassi, 2011).

In Nigeria, companies are mandated by law to pay company income tax on profit earned with $30 \%$, education tax of $2 \%$, withholding tax of $10 \%$ and value-added tax of $5 \%$ in the year/period preceding assessment. Relevant tax authorities includes Federal Inland Revenue Service, State Internal Revenue Service and Local Government Revenue Committee which collect taxes and other charges on behalf of Federal, State and Local government respectively (Madugba, et al., 2015). Corporations embark on corporate tax planning in other to mitigate tax liability legally. This is however expected to result in a positive impact on firm's cash flow and increase its after-tax returns (Nwaobia \& Jayeoba, 2016). Heavy tax burdens exerted negative impact on firm's performance. And equally, Afuberoh and Okoye (2014) opined that revenue derived from taxation has been very low and no physical development has actually take place. Kiabel (2009) is of the view that the shocks from oil price contributes to the reduction of revenue generated by government in the recent years, this prompted the urgent need for government to generate revenue through taxation particularly corporate taxes. However, this study designed to examine the effects of corporate taxation on the profitability of some selected firms in Nigeria

\section{Conceptual Issues}

Taxation: Taxation is process in which society and communities or group of individuals are contributing into an agreed sum for the development and administration of the public (Ogundele, 1999 as cited by Gurama, Mansor and Pantamee, 2015). Soyode and Kajola (2006) equally opined that tax as an obligatory exaction of 
money by a civic authority for public determinations and prosperity. Whereas, Ojo (2008) stressed that taxation is a concept and the science of imposing a tax on citizens of a nation. Afuberoh and Okoye (2014) also considered taxation as a civic duty of the citizenry.

Corporate Tax: Corporate taxes are taxes regulated by companies income tax act (CITA, 1977). Corporate taxes are taxes directly paid by companies periodically to the government of a particular country or nation where it operates. The government imposes corporate taxes on the net profit of the corporations. Aransiola (2013) is of the view that corporate taxes are taxes paid by corporations based on the amount of profit generated. Corporate taxes are taxed on companies, public incorporations and unincorporated associations such as industrial and provident societies, clubs and trade associations Raza, Ali and Abassi (2011). The incidence of corporate tax on companies reduces the fund available for expansion, dividends re-investment, thereby decreases the goods or services produced by such company and also serves as a disincentive to the investing public Ezugwu and Akubo (2014).

Empirical Review: In the study of Riedel and Dischinger (2008), they examined corporate taxes and the location of intangible assets within multinational firms using Multinational Enterprises in Europe. The study found that the lower a subsidiary's tax rate relative to other affiliates of the multinational group, the higher is its level of intangible asset investment. This effect is statistically and economically significant, even after controlling for subsidiary size and accounting for a dynamic intangible investment pattern. Arnold and Schwellnus (2008) examined the effects of corporate taxes on productivity and investment using a stratified sample of firms across OECD economies over the period 1996-2004. The study found that corporate taxes have a negative effect on productivity at the firm level. The effect is negative across firms of different size and age classes except for the small and young, which may be attributable to the relatively low profitability of small and young firms. Raza, Ali and Abassi (2011) investigated the effect of corporate income tax and firms' size on investment: evidence by Karachi stock exchange using multiple regression analysis as a statistical technique for Panel financial Data on an annual basis gathered for the period of six years from 65 sample manufacturing companies.

Their results revealed that there is a negative relationship exists between corporate income tax and investment while firm size and investment reveals a positive relationship with each other. Furthermore, Beigi, Rafat and Panah (2013) investigated the analysis of the effect of the tax on profitability indices in listed companies of Tehran Stock Exchange using approach applied descriptive-analytic and the data of 28 companies listed in Tehran Stock Exchange from 2004 to 2010. The results pointed out a negative significant effect on various profitability indices. It equally indicated that the debts ratio to asset and the type of the industry showed a negative effect on profitability and capital ratio to asset and the size of the company indicated positive significant effects on profitability index. Gatsi, Gadzo and Kportorgbi (2013) investigated the effect of corporate income tax on the financial performance of listed manufacturing firms in Ghana. The study used panel data methodology covering ten listed manufacturing firms for over seven years. Their result revealed that there is a significant negative relationship between corporate income tax and financial performance. On the other hand, firms' size, age of the firm and growth of the firm show a significant positive relationship with financial performance.

Ezugwu and Akubo (2014) carried-out the effect of high corporate tax rate on the profitability of corporate organizations in Nigeria. The population of study comprises the selected corporate organizations while the sample size of the study is forty-one (41) using regression analysis. The study depicted a direct positive relationship between corporate tax rate and realized profit. Also, Chude and Chude (2015) examined the impact of taxation on the profitability of companies in Nigeria. Error correction mechanism was used in the study. The result showed that the level of company tax has a significant effect on the profitability, that company income tax (CIT) has a significant effect on profitability. Madugba, Ekwe, and Kalu, (2015) studied corporate tax and revenue generation: Evidence from Nigeria using Pearson correlation and simple regression were used to analyze the data gotten from Central Bank of Nigeria Annual Statistical Bulletin. The result revealed a negative significant relationship between Petroleum Profit Tax (PPT) and Total Consolidated Revenue (TCR) and Companies Income Tax (CIT). Furthermore, the education tax rate result depicts that the coefficient is 36.28245 and its $\mathrm{p}$-value is 0.0000 . 
Conclusively, several studies have been conducted by previous researchers from developed and developing countries such as Raza, Ali and Abassi (2011); Beigi, Rafat and Panah (2013); Chude and Chude (2015); Maduga, Ekwe and Kalu (2015); Gatsi, Gadzo and Kportorgbi (2013); Riedel and Dischinger (2008); Ezugwu and Akubo (2014); and Arnold and Schwellnus (2008) relating to taxation and corporate taxes on profitability of manufacturing firms. Meanwhile, this study suggested to fill the gap by using Nigeria approved tax rate of $30 \%$ of corporate tax, $2 \%$ education tax, $5 \%$ value-added tax and $10 \%$ withholding tax on the profit before tax of the firms under study. Corporate tax and education tax are paid directly by the selected firms while value-added tax and withholding tax are used as other forms of tax that can also influence the profitability of manufacturing firms.

Figure 1: Conceptual Framework that Shows the Linkage between Corporate Taxes and Profitability of Manufacturing Firms

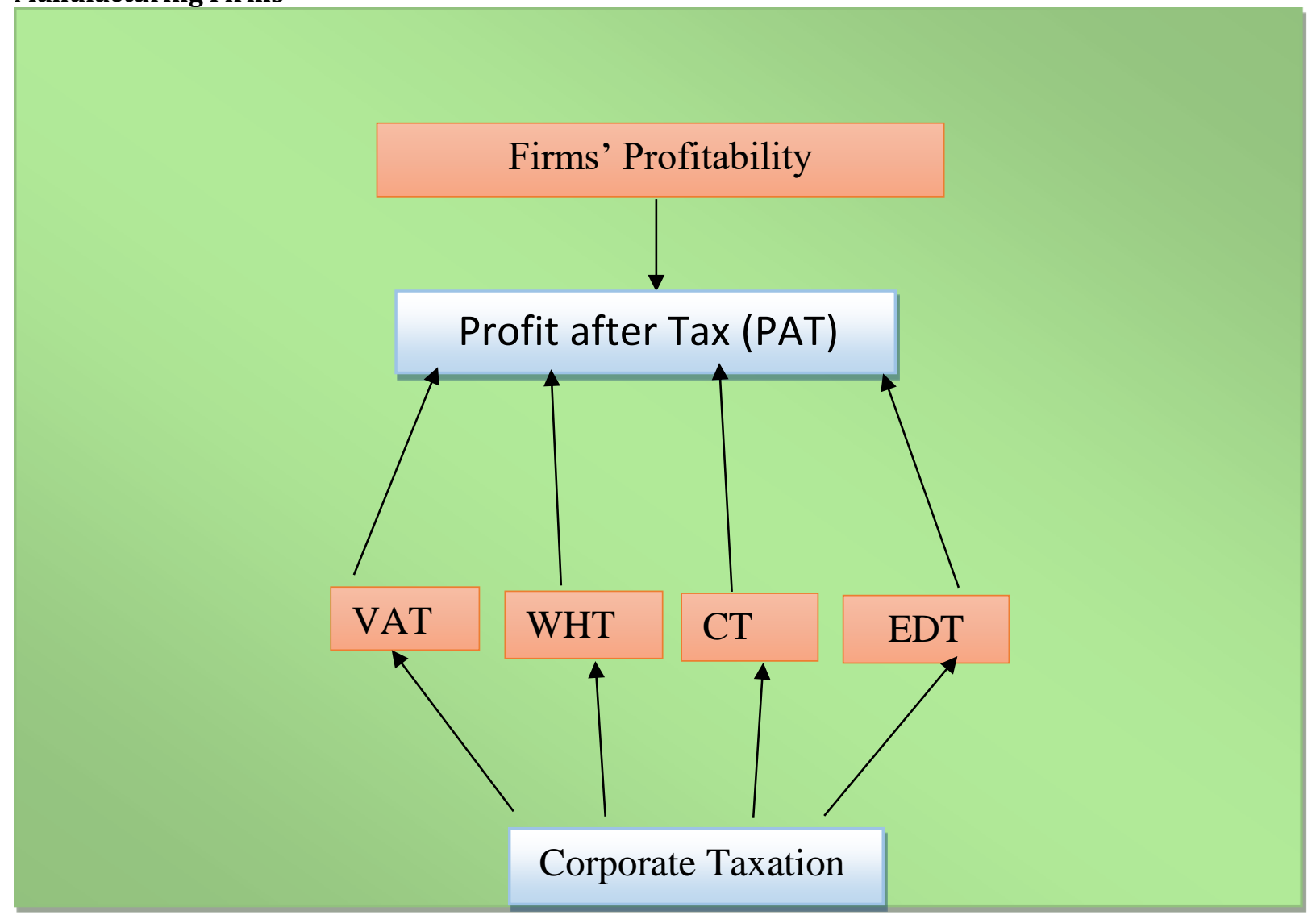

Source: Author's design, (2017)

Where: PAT $=$ Profit after tax, VAT $=$ Value Added Tax, WHT $=$ Withholding Tax, $\mathrm{CT}=$ Corporate Tax, EDT $=$ Education Tax. The above figure 1.0 shows the link between dependable variable (profitability) and the independent variables (corporate tax). The proxies for corporate taxes are value added tax, withholding tax, corporate tax and education tax rate while that of profitability of some selected firms is measured by profit after tax (PAT).

\section{Research Method}

Model Specification: This study modified the work of Ezugwu and Akubo (2014) in examining the effect of high corporate tax rate on the profitability of corporate organizations in Nigeria - A Study of Some Selected Corporate Organization. Their model was specified as:

$\mathrm{CP}=\mathrm{f}(\mathrm{CTR})$ 1

Where: 


\begin{tabular}{l} 
Journal of Economics and Behavioral Studies (ISSN: 2220-6140) \\
Vol. 11, No. 1, pp. 191-201, February 2019 \\
\hline \hline
\end{tabular}

$\mathrm{CP}=$ Corporate Profitability

CTR $=$ Corporate Tax Rates

This study therefore re-modified as stated below:

Whereas;

$$
P A T=f(C T, E D T, V A T, W H T)---------------3
$$

PAT $=$ Profit after Tax

$\mathrm{CT}=$ Corporate $\mathrm{Tax}$

EDT $=$ Education Tax

VAT $=$ Value Added Tax

WHT $=$ Withholding Tax

Estimation Techniques: The model specified in equation 3 is estimated with the use of panel method of econometric analysis. The econometric pooled regression form of the model is presented as follows:

Where:

$$
P A T_{i t}=\beta_{0}-\beta_{1} C T_{i t}-\beta_{2} E D T_{i t}+\beta_{3} V A T_{i t}+\beta_{4} W H T_{i t}+\mu_{i t}-------4
$$

$$
\begin{gathered}
\mu=\text { Error term } \\
\mathrm{i}, \mathrm{t}=\text { Company } \mathrm{i} \text { at time } \mathrm{t} \\
\beta_{0}=\text { Constant parameter } / \text { Intercept } \\
\beta_{1}-\beta_{4}=\text { Coefficients of independent variables }
\end{gathered}
$$

The estimation techniques employed in this study are in the form of Panel analysis and the techniques included panel unit root and pooled OLS test in order to examine the effects of the corporate tax on the profitability of some selected firms in Nigeria. The reason for adopting this is because the data included time-series and crosssectional.

Source of Data: The data used were mainly secondary sources from 2007 to 2016 which were sourced from various annual publication reports of the selected firms. The annual publication reports were reliable because firms are statutorily required to be audited before publication by the auditing firms.

\section{Interpretation of Results, Findings and Discussion}

Panel Unit Root Result: The Levin, Lin \& Chu test was employed in order to analyze the stationarity of the variables. This enables us to determine in, comparative terms, the unit root among the time series also to obtain more robust results.

Table 1: Panel Unit Root at Level

\begin{tabular}{lll}
\hline Variables & Statistic & Prob.** \\
\hline PAT & -8.85973 & 0.0000 \\
CT & -8.29024 & 0.0000 \\
EDT & -8.29024 & 0.0000 \\
VAT & -8.29024 & 0.0000 \\
WHT & -8.29024 & 0.0000 \\
\hline
\end{tabular}

Source: Authors' Compilation (2018)

Table 2: Order of Integration

\begin{tabular}{ll}
\hline Variables & Order of Integration \\
\hline PAT & $1(0)$ \\
CT & $1(0)$ \\
EDT & $1(0)$ \\
VAT & $1(0)$ \\
WHT & $1(0)$ \\
\hline
\end{tabular}

Source: Authors' Compilation (2018)

Tables 1 and 2 present the panel unit root result of variables employed in this study. The reports of the panel unit root test result at level using Levin, Lin and Chu shows that PAT, CT, EDT, VAT and WHT are stationary, 
which brings that all the variables are integrated of order zero I(0). The implication is that PAT, CT, EDT, VAT and WHT used in this study retain innovative shock for a short period of time after which they let go.

\section{Pooled Ordinary Least Square}

Table 3: PAT $=\mathbf{f}(\mathrm{CT})$

\begin{tabular}{lllll}
\hline $\begin{array}{l}\text { Dependent Variable: PAT } \\
\text { Variable }\end{array}$ & Coefficient & Std. Error & t-Statistic & Prob. \\
\hline C & -198977.8 & 159611.4 & -1.246639 & 0.2146 \\
CT & 2.418830 & 0.029697 & 81.45121 & 0.0000 \\
R-squared $\left(\mathrm{R}^{2}\right)$ & 0.978756 & F-statistic & & 6634.299 \\
Adjusted R-squared & 0.978608 & Prob(F-statistic) & & 0.000000 \\
\hline
\end{tabular}

Source: Authors' Compilation (2018)

Table 3 reveals profit after tax as a function of corporate tax. The results of statistical tools reveal that: the coefficient of multiple determination $\left(\mathrm{R}^{2}\right)$ is 0.978756 (97.9\%) implying that the corporate tax can be accounted for over $97 \%$ variation to profit after tax while the remaining per cent is controlled by other factor; the F-test value is 6634.299 and the probability of F-statistic is 0.00000 that is the corporate tax (CT) can influence the dependent variable (PAT). The result also reveals that the coefficient of constant is negative with the value of -198977.8. This means that when the corporate tax is held constant, there will be a negative variation up to the tune of -198977.8 units to profit after tax (PAT). The result equally revealed that the coefficient of corporate tax on profit after tax is positive with the value of 2.418830 and its P-values are 0.0000 which implies that CT has a positive and significant effect on profit after tax in Nigeria that is if there is a unit increase in corporate tax profit after tax will increase with 2.418830 .

Table 4: PAT=f (VAT)

\begin{tabular}{lllll}
\hline $\begin{array}{l}\text { Dependent Variable: PAT } \\
\text { Variable }\end{array}$ & Coefficient & Std. Error & t-Statistic & Prob. \\
\hline C & -198977.8 & 159611.4 & -1.246639 & 0.2146 \\
VAT & 14.51298 & 0.178180 & 81.45121 & 0.0000 \\
R-squared $\left(\mathrm{R}^{2}\right)$ & 0.978756 & F-statistic & & 6634.299 \\
Adjusted R-squared & 0.978608 & Prob(F-statistic) & & 0.000000 \\
\hline
\end{tabular}

Source: Authors' Compilation (2018)

The result of profit after tax as a function of value added tax reveals in Table 4 shows that at constant, the value is negative with tune of -198977.8 and its $p$-value is 0.2146 . This implies that when the value-added tax is held constant there is negative and insignificant effect on profit after tax. The coefficient of value-added tax is 14.51298 and its p-value is 0.0000 . The implication is that value-added tax is positive and has a significant effect on profit after tax that is, if there is a unit increase in value-added tax, profit after tax will equally increase with the tune of 14.51298 simultaneously.

Table 5: PAT $=\mathbf{f}$ (WHT)

\begin{tabular}{lllll}
\hline $\begin{array}{l}\text { Dependent Variable: PAT } \\
\text { Variable }\end{array}$ & Coefficient & Std. Error & t-Statistic & Prob. \\
\hline C & -198977.8 & 159611.4 & -1.246639 & 0.2146 \\
WHT & 7.256489 & 0.089090 & 81.45121 & 0.0000 \\
R-squared $\left(\mathrm{R}^{2}\right)$ & 0.978756 & F-statistic & & 6634.299 \\
Adjusted R-squared & 0.978608 & Prob(F-statistic) & & 0.000000 \\
\hline
\end{tabular}

Source: Authors' Compilation (2018)

Table $5 \mathrm{c}$ presented above reveals profit after tax as a function of withholding tax of some selected company. The result showed that the coefficient of withholding tax as one of the proxies for corporate taxation is positive with the value of 7.256489 and its p-value 0.0000 implying that there exists a positive and significant effect of withholding tax on profit after tax of the selected company. However, withholding tax is one of the taxes 
companies remitted to the government which are being borne by the employee of the company and a unit increase in withholding tax will result to an increase in profit after tax with the tune of 7.256489.

Table 6: PAT $=\mathbf{f}$ (EDT)

\begin{tabular}{lllll}
\hline $\begin{array}{l}\text { Dependent Variable: PAT } \\
\text { Variable }\end{array}$ & Coefficient & Std. Error & t-Statistic & Prob. \\
\hline C & -198977.8 & 159611.4 & -1.246639 & 0.2146 \\
EDT & 36.28245 & 0.445450 & 81.45121 & 0.0000 \\
R-squared $\left(R^{2}\right)$ & 0.978756 & F-statistic & & 6634.299 \\
Adjusted R-squared & 0.978608 & Prob(F-statistic) & & 0.000000 \\
\hline
\end{tabular}

Source: Authors' Compilation (2018)

The Table above revealed profit after tax as a function of education tax (EDT) and the result depicts that education tax coefficient is 36.28245 and its p-value is 0.0000 . The implication is that education tax has a positive and significant effects on profit after tax that is, a unit increase in education tax will lead to an increase in profit after tax with the tune of 36.28245 .

Discussion: From the analysis, the study found out that the Levin, Lin and Chu unit root result showed that all the variables employed are stationary at level, which brings that all the variables were integrated of order zero $\mathrm{I}(0)$. The pooled ordinary least square revealed that the coefficient of multiple determinants $\left(\mathrm{R}^{2}\right)$ with over 97\%; the adjusted R-square, the F-test and the prob (F-statistic) were statistically significant. Furthermore, the coefficient of corporate tax on profit after tax was positive with the value of 2.418830 and its P-values were 0.0000 , the coefficient of value-added tax was 14.51298 and it p-value was 0.0000 . Equally, the coefficient of withholding tax was positive with the value of 7.256489 with p-value 0.0000 . This implies that manufacturing firms use Tax Avenue to jack up their returns by increasing their product before sales. However, the findings of this study are similar to the work of Chude and Chude (2015); Maduga, Ekwe and Kalu (2015).

\section{Conclusion and Recommendations}

This study empirically reviews the effects of corporate taxation on the profitability of some selected firms in Nigeria employing corporate tax rate, education tax rate, value-added tax rate and withholding tax rate as the proxies for corporate taxation and profit after tax as a proxy for the profitability of the selected firms. The study, however, concluded that corporate tax rate and education tax rate as the major taxes paid by companies have positive and significant effects to influence profit after tax. It is also clinched that value-added tax and withholding tax being used as other variables that could have effects on profit after tax equally revealed positive and significant effects on profit after tax. Therefore, the study recommended that the government and relevant tax authorities should improve in the administration of corporate taxes to avoid non-compliance being that the taxes paid by the companies are added on the product aside from the prospective gains.

\section{References}

Aransiola, S. Y. (2013). Corporate tax and investment Decision in quoted manufacturing industries in Nigeria. Open Journal Of Industrial And Business Management. Doi: 1012966/ojibm

Arnold, J. \& Schwellnus, C. (2008). The effects of corporate taxes on productivity and investment across OECD economies over the period, 1996- 2004.

Afuberoh, D. \& Okoye, E. (2014). The impact of taxation on revenue generation in Nigeria. A study of federal capital territory and selected states. International Journal of Public Administration and Management Research (IJPAMR), 0012(2), 23-37.

Beigi, M. R., Rafat, B. \& Panah, H. M. (2013). The analysis of the effect of tax on profitability indices in listed companies of Tehran Stock Exchange. European Online Journal of Natural and Social Sciences, 2(3), 8698.

Chude, D. I. \& Chude, N. P. (2015). The impact of company income taxation on the profitability of companies in Nigeria: a study of Nigerian Breweries. European Journal of Accounting, Auditing and Finance Research, $3(8), 1-11$. 
Ezugwu, C. I. \& Akubo, D. (2014). Analysis of the Effect of High Corporate Tax Rate on the Profitability of Corporate Organizations in Nigeria - A Study of Some Selected Corporate Organizations. Mediterranean Journal of Social Sciences, 5(20), 311-321.

Gurama, Z., Mansor, M. B. \& Pantamee, A. A. (2015). Tax Evasion and Nigeria Tax System: An Overview. Research Journal of Finance and Accounting, 6(8), 202-211.

Gatsi, J. G., Gadzo, S. G. \& Kportorgbi, H. K. (2013). The effect of corporate income tax on financial performance of listed manufacturing firms in Ghana. Research Journal of Finance Accounting, 4(15), 118-124.

Kiabel, D. B. (2009). Curbing Tax Evasion and Avoidance in personal income tax administrations. A study of the South-South states of Nigeria. European journal of Economies, Financial Administrative Sciences. ISSN 1450-2275. Issue 15. http//:www.eurojournals.com/EJEPAS.

Madugba, J. U., Ekwe, M. C. \& Kalu, J. M. (2015). Corporate Tax and Revenue Generation: Evidence from Nigeria. Journal of Emerging Trends in Economics and Management Sciences, 6(5), 333-339.

Nightingale, K. (1997). Taxation: Theory and Practice. Pitman. United Kingdom

Nwaobia, A. N. \& Jayeoba, O. O. (2016). Tax planning and firm's liquidity. Journal of Business Management, 2(10), $1-22$.

Ogundele, A. E. (1999). Elements of Taxation. 1st Edition: Libri Service, Lagos.

Ojo, S. (2008). Fundamental principles of Nigerian tax. Lagos Sagribra Pax publication second edition

Raza, S. A., Ali, S. A. \& Abassi, Z. (2011). Effect of corporate income tax and firms' size on investment: evidence by Karachi stock exchange.

Riedel, M. \& Dischinger, N. (2008). Corporate Taxes and the Location of Intangible Assets within Multinational Firms. Munich Discussion Paper No.15.

Soyode, I. \& Kajola, S. O. (2006). Taxation principles and practice in Nigeria. Ibadan: Silicon publishers.

\begin{tabular}{|c|c|c|c|c|c|c|c|c|}
\hline $\begin{array}{l}\text { Date } \\
\text { d }\end{array}$ & Firms & Year & PAT & PBT & VAT $5 \%$ PBT & WHT 10\% PBT & CIT 30\%PBT & \begin{tabular}{l|l} 
EDT \\
2\%PBT \\
\end{tabular} \\
\hline 1 & Flour Mill & 2007 & $7,474,468$ & $9,791,772$ & 489588.6 & 979177.2 & 2937531.6 & 195835.44 \\
\hline 1 & Flour Mill & 2008 & $6,363,082$ & $9,878,183$ & 493909.15 & 987818.3 & 2963454.9 & 197563.66 \\
\hline 1 & Flour Mill & 2009 & $3,892,183$ & $5,470,222$ & 273511.1 & 547022.2 & 1641066.6 & 109404.44 \\
\hline 1 & Flour Mill & 2010 & $13,370,731$ & $19,300,962$ & 965048.1 & 1930096.2 & 5790288.6 & 386019.24 \\
\hline 1 & Flour Mill & 2011 & $10,095,752$ & $14,264,723$ & 713236.15 & 1426472.3 & 4279416.9 & 285294.46 \\
\hline 1 & Flour Mill & 2012 & $11,803,161$ & $7,761,629$ & 388081.45 & 776162.9 & 2328488.7 & 155232.58 \\
\hline 1 & Flour Mill & 2013 & $11,803,161$ & $7,826,082$ & 391304.1 & 782608.2 & 2347824.6 & 156521.64 \\
\hline 1 & Flour Mill & 2014 & $7,686,943$ & $4,369,300$ & 218465 & 436930 & 1310790 & 87386 \\
\hline 1 & Flour Mill & 2015 & $7,724,770$ & $8,474,342$ & 423717.1 & 847434.2 & 2542302.6 & 169486.84 \\
\hline 1 & Flour Mill & 2016 & $11,489,278$ & $14,420,284$ & 721014.2 & 1442028.4 & 4326085.2 & 288405.68 \\
\hline 2 & Nestle & 2007 & $5,441,899$ & $8,463,788$ & 423189.4 & 846378.8 & 2539136.4 & 169275.76 \\
\hline 2 & Nestle & 2008 & $9,783,578$ & $11,862,213$ & 593110.65 & 1186221.3 & 3558663.9 & 237244.26 \\
\hline 2 & Nestle & 2009 & $8,331,599$ & $13,783,244$ & 689162.2 & 1378324.4 & 4134973.2 & 275664.88 \\
\hline 2 & Nestle & 2010 & $12,602,109$ & $18,244,454$ & 912222.7 & 1824445.4 & 5473336.2 & 364889.08 \\
\hline 2 & Nestle & 2011 & $16,496,453$ & $18,199,249$ & 909962.45 & 1819924.9 & 5459774.7 & 363984.98 \\
\hline 2 & Nestle & 2012 & $21,137,275$ & $25,050,172$ & 1252508.6 & 2505017.2 & 7515051.6 & 501003.44 \\
\hline 2 & Nestle & 2013 & $22,258,279$ & $26,047,590$ & 1302379.5 & 2604759 & 7814277 & 520951.8 \\
\hline 2 & Nestle & 2014 & $22,235,640$ & $24,445,978$ & 1222298.9 & 2444597.8 & 7333793.4 & 488919.56 \\
\hline 2 & Nestle & 2015 & $23,736,777$ & $29,322,477$ & 1466123.9 & 2932247.7 & 8796743.1 & 586449.54 \\
\hline 2 & Nestle & 2016 & $7,924,968$ & & 0 & 0 & 0 & 0 \\
\hline 3 & Unilever & 2007 & $1,296,533$ & $2,013,148$ & 100657.4 & 201314.8 & 603944.4 & 40262.96 \\
\hline 3 & Unilever & 2008 & $2,596,533$ & $4,144,849$ & 207242.45 & 414484.9 & 1243454.7 & 82896.98 \\
\hline 3 & Unilever & 2009 & $4,093,822$ & $5,661,052$ & 283052.6 & 566105.2 & 1698315.6 & 113221.04 \\
\hline
\end{tabular}




\begin{tabular}{|c|c|c|c|c|c|c|c|c|}
\hline 3 & Unilever & 2010 & $4,180,620$ & $6,151,855$ & 307592.75 & 615185.5 & 1845556.5 & 123037.1 \\
\hline 3 & Unilever & 2011 & $5,491,076$ & $7,983,312$ & 399165.6 & 798331.2 & 2394993.6 & 159666.24 \\
\hline 3 & Unilever & 2012 & $5,597,613$ & $8,185,987$ & 409299.35 & 818598.7 & 2455796.1 & 163719.74 \\
\hline 3 & Unilever & 2013 & $4,806,907$ & $6,911,441$ & 345572.05 & 691144.1 & 2073432.3 & 138228.82 \\
\hline 3 & Unilever & 2014 & $2,412,343$ & $2,873,235$ & 143661.75 & 287323.5 & 861970.5 & 57464.7 \\
\hline 3 & Unilever & 2015 & $1,192,366$ & $1,771,063$ & 88553.15 & 177106.3 & 531318.9 & 35421.26 \\
\hline 3 & Unilever & 2016 & $3,071,885$ & $4,106,422$ & 205321.1 & 410642.2 & 1231926.6 & 82128.44 \\
\hline 4 & Cadbury & 2007 & & & 0 & 0 & 0 & 0 \\
\hline 4 & Cadbury & 2008 & $-2,752$ & $-2,848$ & -142.4 & -284.8 & -854.4 & -56.96 \\
\hline 4 & Cadbury & 2009 & $-2,752$ & $-2,848$ & -142.4 & -284.8 & -854.4 & -56.96 \\
\hline 4 & Cadbury & 2010 & 1,952 & 1,143 & 57.15 & 114.3 & 342.9 & 22.86 \\
\hline 4 & Cadbury & 2011 & $3,670,555$ & $5,053,022$ & 252651.1 & 505302.2 & 1515906.6 & 101060.44 \\
\hline 4 & Cadbury & 2012 & $3,454,991$ & $5,511,518$ & 275575.9 & 551151.8 & 1653455.4 & 110230.36 \\
\hline 4 & Cadbury & 2013 & $6,606,013$ & $8,278,526$ & 413926.3 & 827852.6 & 2483557.8 & 165570.52 \\
\hline 4 & Cadbury & 2014 & $2,137,319$ & $2,385,891$ & 119294.55 & 238589.1 & 715767.3 & 47717.82 \\
\hline 4 & Cadbury & 2015 & $1,153,295$ & $1,577,412$ & 78870.6 & 157741.2 & 473223.6 & 31548.24 \\
\hline 4 & $\begin{array}{l}\text { Cadbury } \\
\text { Dangote }\end{array}$ & 2016 & $-296,402$ & $-562,870$ & -28143.5 & -56287 & -168861 & -11257.4 \\
\hline 5 & $\begin{array}{l}\text { Flour } \\
\text { Dangote }\end{array}$ & 2007 & $21,478,561$ & $30,660,730$ & 1533036.5 & 3066073 & 9198219 & 613214.6 \\
\hline 5 & $\begin{array}{l}\text { Flour } \\
\text { Dangote }\end{array}$ & 2008 & $21,871,047$ & $30,151,378$ & 1507568.9 & 3015137.8 & 9045413.4 & 603027.56 \\
\hline 5 & $\begin{array}{l}\text { Flour } \\
\text { Dangote }\end{array}$ & 2009 & $13,185,599$ & $19,586,932$ & 979346.6 & 1958693.2 & 5876079.6 & 391738.64 \\
\hline 5 & $\begin{array}{l}\text { Flour } \\
\text { Dangote }\end{array}$ & 2010 & $2,762,142$ & $4,911,885$ & 245594.25 & 491188.5 & 1473565.5 & 98237.7 \\
\hline 5 & $\begin{array}{l}\text { Flour } \\
\text { Dangote }\end{array}$ & 2011 & 623,622 & 758,742 & 37937.1 & 75874.2 & 227622.6 & 15174.84 \\
\hline 5 & $\begin{array}{l}\text { Flour } \\
\text { Dangote }\end{array}$ & 2012 & $-2,769,723$ & $-5,602,972$ & -280148.6 & -560297.2 & -1680892 & -112059.4 \\
\hline 5 & $\begin{array}{l}\text { Flour } \\
\text { Dangote }\end{array}$ & 2013 & $-7,932,996$ & $-8,342,294$ & -417114.7 & -834229.4 & -2502688 & -166845.9 \\
\hline 5 & $\begin{array}{l}\text { Flour } \\
\text { Dangote }\end{array}$ & 2014 & $\begin{array}{l}-6,219,904 \\
-\end{array}$ & $\begin{array}{l}-9,285,013 \\
-\end{array}$ & -464250.7 & -928501.3 & -2785504 & -185700.3 \\
\hline 5 & $\begin{array}{l}\text { Flour } \\
\text { Dangote }\end{array}$ & 2015 & $14,078,794$ & $13,789,416$ & -689470.8 & -1378942 & -4136825 & -275788.3 \\
\hline 5 & $\begin{array}{l}\text { Flour } \\
\text { First }\end{array}$ & 2016 & $12,110,356$ & $11,588,399$ & 579419.95 & 1158839.9 & 3476519.7 & 231767.98 \\
\hline 6 & $\begin{array}{l}\text { Aluminium } \\
\text { First }\end{array}$ & 2007 & $-491,584$ & $-583,106$ & -29155.3 & -58310.6 & -174931.8 & -11662.12 \\
\hline 6 & $\begin{array}{l}\text { Aluminium } \\
\text { First }\end{array}$ & 2008 & $-298,652$ & $-473,092$ & -23654.6 & -47309.2 & -141927.6 & -9461.84 \\
\hline 6 & $\begin{array}{l}\text { Aluminium } \\
\text { First }\end{array}$ & 2009 & 48,316 & 59,621 & 2981.05 & 5962.1 & 17886.3 & 1192.42 \\
\hline 6 & $\begin{array}{l}\text { Aluminium } \\
\text { First }\end{array}$ & 2010 & $-334,586$ & $-298,070$ & -14903.5 & -29807 & -89421 & -5961.4 \\
\hline 6 & $\begin{array}{l}\text { Aluminium } \\
\text { First }\end{array}$ & 2011 & $-325,044$ & $-278,223$ & -13911.15 & -27822.3 & -83466.9 & -5564.46 \\
\hline 6 & $\begin{array}{l}\text { Aluminium } \\
\text { First }\end{array}$ & 2012 & $-1,004,392$ & $-1,053,239$ & -52661.95 & -105323.9 & -315971.7 & -21064.78 \\
\hline 6 & $\begin{array}{l}\text { Aluminium } \\
\text { First }\end{array}$ & 2013 & 99,170 & 29,761 & 1488.05 & 2976.1 & 8928.3 & 595.22 \\
\hline 6 & $\begin{array}{l}\text { Aluminium } \\
\text { First }\end{array}$ & 2014 & 31,742 & 106,385 & 5319.25 & 10638.5 & 31915.5 & 2127.7 \\
\hline 6 & $\begin{array}{l}\text { Aluminium } \\
\text { First }\end{array}$ & 2015 & 112,554 & 43,172 & 2158.6 & 4317.2 & 12951.6 & 863.44 \\
\hline 6 & Aluminium & 2016 & 165,420 & 271,620 & 13581 & 27162 & 81486 & 5432.4 \\
\hline 7 & Guinness & 2007 & $10,691,060$ & $14,884,450$ & 744222.5 & 1488445 & 4465335 & 297689 \\
\hline
\end{tabular}




\begin{tabular}{|c|c|c|c|c|c|c|c|c|}
\hline 7 & Guinness & 2008 & $11,860,880$ & $17,092,950$ & 854647.5 & 1709295 & 5127885 & 341859 \\
\hline 7 & Guinness & 2009 & $13,541,189$ & $18,991,762$ & 949588.1 & 1899176.2 & 5697528.6 & 379835.24 \\
\hline 7 & Guinness & 2010 & $13,736,359$ & $19,988,735$ & 999436.75 & 1998873.5 & 5996620.5 & 399774.7 \\
\hline 7 & Guinness & 2011 & $17,927,934$ & $26,176,966$ & 1308848.3 & 2617696.6 & 7853089.8 & 523539.32 \\
\hline 7 & Guinness & 2012 & $14,671,195$ & $21,074,950$ & 1053747.5 & 2107495 & 6322485 & 421499 \\
\hline 7 & Guinness & 2013 & $11,863,726$ & $17,008,875$ & 850443.75 & 1700887.5 & 5102662.5 & 340177.5 \\
\hline 7 & Guinness & 2014 & $9,573,480$ & $11,681,560$ & 584078 & 1168156 & 3504468 & 233631.2 \\
\hline 7 & Guinness & 2015 & $7,794,899$ & $10,795,102$ & 539755.1 & 1079510.2 & 3238530.6 & 215902.04 \\
\hline 7 & $\begin{array}{l}\text { Guinness } \\
\text { Nigeria }\end{array}$ & 2016 & $-2,015,886$ & $-2,347,241$ & -117362.1 & -234724.1 & -704172.3 & -46944.82 \\
\hline 8 & $\begin{array}{l}\text { Beweries } \\
\text { Nigeria }\end{array}$ & 2007 & $18,942,856$ & $27,876,336$ & 1393816.8 & 2787633.6 & 8362900.8 & 557526.72 \\
\hline 8 & $\begin{array}{l}\text { Beweries } \\
\text { Nigeria }\end{array}$ & 2008 & $25,700,593$ & $37,519,114$ & 1875955.7 & 3751911.4 & 11255734 & 750382.28 \\
\hline 8 & $\begin{array}{l}\text { Beweries } \\
\text { Nigeria }\end{array}$ & 2009 & $27,910,091$ & $41,399,796$ & 2069989.8 & 4139979.6 & 12419939 & 827995.92 \\
\hline 8 & $\begin{array}{l}\text { Beweries } \\
\text { Nigeria }\end{array}$ & 2010 & $30,332,118$ & $44,880,248$ & 2244012.4 & 4488024.8 & 13464074 & 897604.96 \\
\hline 8 & $\begin{array}{l}\text { Beweries } \\
\text { Nigeria }\end{array}$ & 2011 & $38,408,847$ & $57,118,042$ & 2855902.1 & 5711804.2 & 17135413 & 1142360.8 \\
\hline 8 & $\begin{array}{l}\text { Beweries } \\
\text { Nigeria }\end{array}$ & 2012 & $38,042,714$ & $55,624,366$ & 2781218.3 & 5562436.6 & 16687310 & 1112487.3 \\
\hline 8 & $\begin{array}{l}\text { Beweries } \\
\text { Nigeria }\end{array}$ & 2013 & $43,080,349$ & $62,240,317$ & 3112015.9 & 6224031.7 & 18672095 & 1244806.3 \\
\hline 8 & $\begin{array}{l}\text { Beweries } \\
\text { Nigeria }\end{array}$ & 2014 & $42,520,253$ & $61,461,821$ & 3073091.1 & 6146182.1 & 18438546 & 1229236.4 \\
\hline 8 & $\begin{array}{l}\text { Beweries } \\
\text { Nigeria }\end{array}$ & 2015 & $38,049,318$ & $54,508,368$ & 2725418.4 & 5450836.8 & 16352510 & 1090167.4 \\
\hline 8 & Beweries & 2016 & $28,396,777$ & $39,622,914$ & 1981145.7 & 3962291.4 & 11886874 & 792458.28 \\
\hline 9 & $\mathrm{PZ}$ & 2007 & $3,512,347$ & $5,355,885$ & 267794.25 & 535588.5 & 1606765.5 & 107117.7 \\
\hline 9 & $\mathrm{PZ}$ & 2008 & $3,950,935$ & $5,980,297$ & 299014.85 & 598029.7 & 1794089.1 & 119605.94 \\
\hline 9 & $\mathrm{PZ}$ & 2009 & $4,818,611$ & $7,671,087$ & 383554.35 & 767108.7 & 2301326.1 & 153421.74 \\
\hline 9 & $\mathrm{PZ}$ & 2010 & $5,301,742$ & $7,951,448$ & 397572.4 & 795144.8 & 2385434.4 & 159028.96 \\
\hline 9 & $\mathrm{PZ}$ & 2011 & $5,217,530$ & $8,025,266$ & 401263.3 & 802526.6 & 2407579.8 & 160505.32 \\
\hline 9 & $\mathrm{PZ}$ & 2012 & $2,410,498$ & $4,306,863$ & 215343.15 & 430686.3 & 1292058.9 & 86137.26 \\
\hline 9 & $\mathrm{PZ}$ & 2013 & $4,875,040$ & $7,650,265$ & 382513.25 & 765026.5 & 2295079.5 & 153005.3 \\
\hline 9 & $\mathrm{PZ}$ & 2014 & $4,591,399$ & $6,949,985$ & 347499.25 & 694998.5 & 2084995.5 & 138999.7 \\
\hline 9 & $\mathrm{PZ}$ & 2015 & $4,053,284$ & $6,556,814$ & 327840.7 & 655681.4 & 1967044.2 & 131136.28 \\
\hline 9 & $\mathrm{PZ}$ & 2016 & $1,863,013$ & $3,148,196$ & 157409.8 & 314819.6 & 944458.8 & 62963.92 \\
\hline 10 & Beta Glass & 2007 & 866,252 & $1,056,841$ & 52842.05 & 105684.1 & 317052.3 & 21136.82 \\
\hline 10 & Beta Glass & 2008 & $1,192,690$ & $1,453,360$ & 72668 & 145336 & 436008 & 29067.2 \\
\hline 10 & Beta Glass & 2009 & $1,384,776$ & $1,813,400$ & 90670 & 181340 & 544020 & 36268 \\
\hline 10 & Beta Glass & 2010 & $1,472,444$ & $1,832,403$ & 91620.15 & 183240.3 & 549720.9 & 36648.06 \\
\hline 10 & Beta Glass & 2011 & $1,774,660$ & $2,300,357$ & 115017.85 & 230035.7 & 690107.1 & 46007.14 \\
\hline 10 & Beta Glass & 2012 & $1,328,580$ & $1,857,089$ & 92854.45 & 185708.9 & 557126.7 & 37141.78 \\
\hline 10 & Beta Glass & 2013 & $1,560,164$ & $2,138,784$ & 106939.2 & 213878.4 & 641635.2 & 42775.68 \\
\hline 10 & Beta Glass & 2014 & $2,390,223$ & $3,340,660$ & 167033 & 334066 & 1002198 & 66813.2 \\
\hline 10 & Beta Glass & 2015 & $1,991,127$ & $3,114,795$ & 155739.75 & 311479.5 & 934438.5 & 62295.9 \\
\hline 10 & $\begin{array}{l}\text { Beta Glass } \\
\text { Dangote }\end{array}$ & 2016 & & & 0 & 0 & 0 & 0 \\
\hline 11 & Sugar & 2007 & $21,478,561$ & $30,660,730$ & 1533036.5 & 3066073 & 9198219 & 613214.6 \\
\hline
\end{tabular}


Journal of Economics and Behavioral Studies (ISSN: 2220-6140)

Vol. 11, No. 1, pp. 191-201, February 2019

\begin{tabular}{|c|c|c|c|c|c|c|c|c|}
\hline 11 & $\begin{array}{l}\text { Dangote } \\
\text { Sugar } \\
\text { Dangote }\end{array}$ & 2008 & $21,871,047$ & $30,151,378$ & 1507568.9 & 3015137.8 & 9045413.4 & 603027.56 \\
\hline 11 & $\begin{array}{l}\text { Sugar } \\
\text { Dangote }\end{array}$ & 2009 & $13,185,599$ & $19,587,423$ & 979371.15 & 1958742.3 & 5876226.9 & 391748.46 \\
\hline 11 & $\begin{array}{l}\text { Sugar } \\
\text { Dangote }\end{array}$ & 2010 & $11,282,240$ & $16,146,930$ & 807346.5 & 1614693 & 4844079 & 322938.6 \\
\hline 11 & $\begin{array}{l}\text { Sugar } \\
\text { Dangote }\end{array}$ & 2011 & $7,403,597$ & $10,921,229$ & 546061.45 & 1092122.9 & 3276368.7 & 218424.58 \\
\hline 11 & $\begin{array}{l}\text { Sugar } \\
\text { Dangote }\end{array}$ & 2012 & $10,796,416$ & $16,331,679$ & 816583.95 & 1633167.9 & 4899503.7 & 326633.58 \\
\hline 11 & $\begin{array}{l}\text { Sugar } \\
\text { Dangote }\end{array}$ & 2013 & $13,537,612$ & $20,099,517$ & 1004975.9 & 2009951.7 & 6029855.1 & 401990.34 \\
\hline 11 & $\begin{array}{l}\text { Sugar } \\
\text { Dangote }\end{array}$ & 2014 & $11,908,690$ & $17,472,841$ & 873642.05 & 1747284.1 & 5241852.3 & 349456.82 \\
\hline 11 & $\begin{array}{l}\text { Sugar } \\
\text { Dangote }\end{array}$ & 2015 & $12,659,855$ & $18,144,955$ & 907247.75 & 1814495.5 & 5443486.5 & 362899.1 \\
\hline 11 & $\begin{array}{l}\text { Sugar } \\
\text { Okomu }\end{array}$ & 2016 & $14,395,938$ & $19,614,434$ & 980721.7 & 1961443.4 & 5884330.2 & 392288.68 \\
\hline 12 & $\begin{array}{l}\text { Palm } \\
\text { Okomu }\end{array}$ & 2007 & 139,794 & 150,794 & 7539.7 & 15079.4 & 45238.2 & 3015.88 \\
\hline 12 & $\begin{array}{l}\text { Palm } \\
\text { Okomu }\end{array}$ & 2008 & $1,207,460$ & $1,240,038$ & 62001.9 & 124003.8 & 372011.4 & 24800.76 \\
\hline 12 & $\begin{array}{l}\text { Palm } \\
\text { Okomu }\end{array}$ & 2009 & 549,410 & 661,627 & 33081.35 & 66162.7 & 198488.1 & 13232.54 \\
\hline 12 & $\begin{array}{l}\text { Palm } \\
\text { Okomu }\end{array}$ & 2010 & $1,629,456$ & $1,971,262$ & 98563.1 & 197126.2 & 591378.6 & 39425.24 \\
\hline 12 & $\begin{array}{l}\text { Palm } \\
\text { Okomu }\end{array}$ & 2011 & $3,446,905$ & $4,181,486$ & 209074.3 & 418148.6 & 1254445.8 & 83629.72 \\
\hline 12 & $\begin{array}{l}\text { Palm } \\
\text { Okomu }\end{array}$ & 2012 & $3,416,288$ & $4,072,185$ & 203609.25 & 407218.5 & 1221655.5 & 81443.7 \\
\hline 12 & $\begin{array}{l}\text { Palm } \\
\text { Okomu }\end{array}$ & 2013 & $2,085,920$ & $2,687,301$ & 134365.05 & 268730.1 & 806190.3 & 53746.02 \\
\hline 12 & $\begin{array}{l}\text { Palm } \\
\text { Okomu Oil }\end{array}$ & 2014 & $1,453,320$ & $1,904,496$ & 95224.8 & 190449.6 & 571348.8 & 38089.92 \\
\hline 12 & $\begin{array}{l}\text { Palm } \\
\text { Okomu Oil }\end{array}$ & 2015 & $2,697,555$ & $2,898,645$ & 144932.25 & 289864.5 & 869593.5 & 57972.9 \\
\hline 12 & Palm & 2016 & $4,910,273$ & $5,906,453$ & 295322.65 & 590645.3 & 1771935.9 & 118129.06 \\
\hline 13 & Glaxosmith & 2007 & 836,876 & $1,166,449$ & 58322.45 & 116644.9 & 349934.7 & 23328.98 \\
\hline 13 & Glaxosmith & 2008 & $1,277,441$ & $1,851,364$ & 92568.2 & 185136.4 & 555409.2 & 37027.28 \\
\hline 13 & Glaxosmith & 2009 & $1,701,829$ & $2,469,596$ & 123479.8 & 246959.6 & 740878.8 & 49391.92 \\
\hline 13 & Glaxosmith & 2010 & $2,461,395$ & $3,370,886$ & 168544.3 & 337088.6 & 1011265.8 & 67417.72 \\
\hline 13 & Glaxosmith & 2011 & $2,294,988$ & $3,492,620$ & 174631 & 349262 & 1047786 & 69852.4 \\
\hline 13 & Glaxosmith & 2012 & $2,823,526$ & $4,171,665$ & 208583.25 & 417166.5 & 1251499.5 & 83433.3 \\
\hline 13 & Glaxosmith & 2013 & $2,919,170$ & $4,314,829$ & 215741.45 & 431482.9 & 1294448.7 & 86296.58 \\
\hline 13 & Glaxosmith & 2014 & $1,848,842$ & $2,752,216$ & 137610.8 & 275221.6 & 825664.8 & 55044.32 \\
\hline 13 & Glaxosmith & 2015 & 965,047 & $1,157,514$ & 57875.7 & 115751.4 & 347254.2 & 23150.28 \\
\hline 13 & Glaxosmith & 2016 & & & 0 & 0 & 0 & 0 \\
\hline 14 & WEMA & 2007 & $\begin{array}{l}2,554,098 \\
-\end{array}$ & $\begin{array}{l}1,878,698 \\
-\end{array}$ & 93934.9 & 187869.8 & 563609.4 & 37573.96 \\
\hline 14 & WEMA & 2008 & $\begin{array}{l}57,738,739 \\
-\end{array}$ & $\begin{array}{l}68,482,164 \\
-\end{array}$ & -3424108 & -6848216 & -20544649 & -1369643 \\
\hline 14 & WEMA & 2009 & $11,668,408$ & $19,436,874$ & -971843.7 & -1943687 & -5831062 & -388737.5 \\
\hline 14 & WEMA & 2010 & $9,689,683$ & $12,964,108$ & 648205.4 & 1296410.8 & 3889232.4 & 259282.16 \\
\hline 14 & WEMA & 2011 & $-4,228,926$ & $-3,770,021$ & -188501.1 & -377002.1 & -1131006 & -75400.42 \\
\hline 14 & WEMA & 2012 & $-5,040,629$ & $-4,942,211$ & -247110.6 & -494221.1 & -1482663 & -98844.22 \\
\hline 14 & WEMA & 2013 & $1,596,531$ & $1,947,308$ & 97365.4 & 194730.8 & 584192.4 & 38946.16 \\
\hline 14 & WEMA & 2014 & $2,372,445$ & $3,093,940$ & 154697 & 309394 & 928182 & 61878.8 \\
\hline
\end{tabular}




\begin{tabular}{|c|c|c|c|c|c|c|c|c|}
\hline \multicolumn{9}{|c|}{$\begin{array}{l}\text { Journal of Economics and Behavioral Studies (ISSN: 2220-6140) } \\
\text { Vol. 11, No. 1, pp. 191-201, February } 2019\end{array}$} \\
\hline 14 & WEMA & 2015 & $2,327,275$ & $3,045,528$ & 152276.4 & 304552.8 & 913658.4 & 60910.56 \\
\hline 14 & WEMA & 2016 & $2,560,580$ & $3,245,145$ & 162257.25 & 324514.5 & 973543.5 & 64902.9 \\
\hline 15 & Julius Berger & 2007 & $1,763,706$ & $3,132,048$ & 156602.4 & 313204.8 & 939614.4 & 62640.96 \\
\hline 15 & Julius Berger & 2008 & $2,452,427$ & $5,170,401$ & 258520.05 & 517040.1 & 1551120.3 & 103408.02 \\
\hline 15 & Julius Berger & 2009 & $3,259,122$ & $9,369,147$ & 468457.35 & 936914.7 & 2810744.1 & 187382.94 \\
\hline 15 & Julius Berger & 2010 & $2,774,825$ & $7,962,201$ & 398110.05 & 796220.1 & 2388660.3 & 159244.02 \\
\hline 15 & Julius Berger & 2011 & $4,411,998$ & $9,933,147$ & 496657.35 & 993314.7 & 2979944.1 & 198662.94 \\
\hline 15 & Julius Berger & 2012 & $8,193,543$ & $12,341,492$ & 617074.6 & 1234149.2 & 3702447.6 & 246829.84 \\
\hline 15 & Julius Berger & 2013 & $8,064,235$ & $16,220,536$ & 811026.8 & 1622053.6 & 4866160.8 & 324410.72 \\
\hline 15 & Julius Berger & 2014 & $8,088,795$ & $13,134,896$ & 656744.8 & 1313489.6 & 3940468.8 & 262697.92 \\
\hline 15 & Julius Berger & 2015 & $1,759,889$ & $6,499,973$ & 324998.65 & 649997.3 & 1949991.9 & 129999.46 \\
\hline 15 & Julius Berger & 2016 & $3,015,014$ & $4,513,043$ & 225652.15 & 451304.3 & 1353912.9 & 90260.86 \\
\hline
\end{tabular}

